\title{
Law, history, colonialism
}

\section{The reach of empire}

EDITED BY DIANE KIRKBY \& CATHARINE COLEBORNE

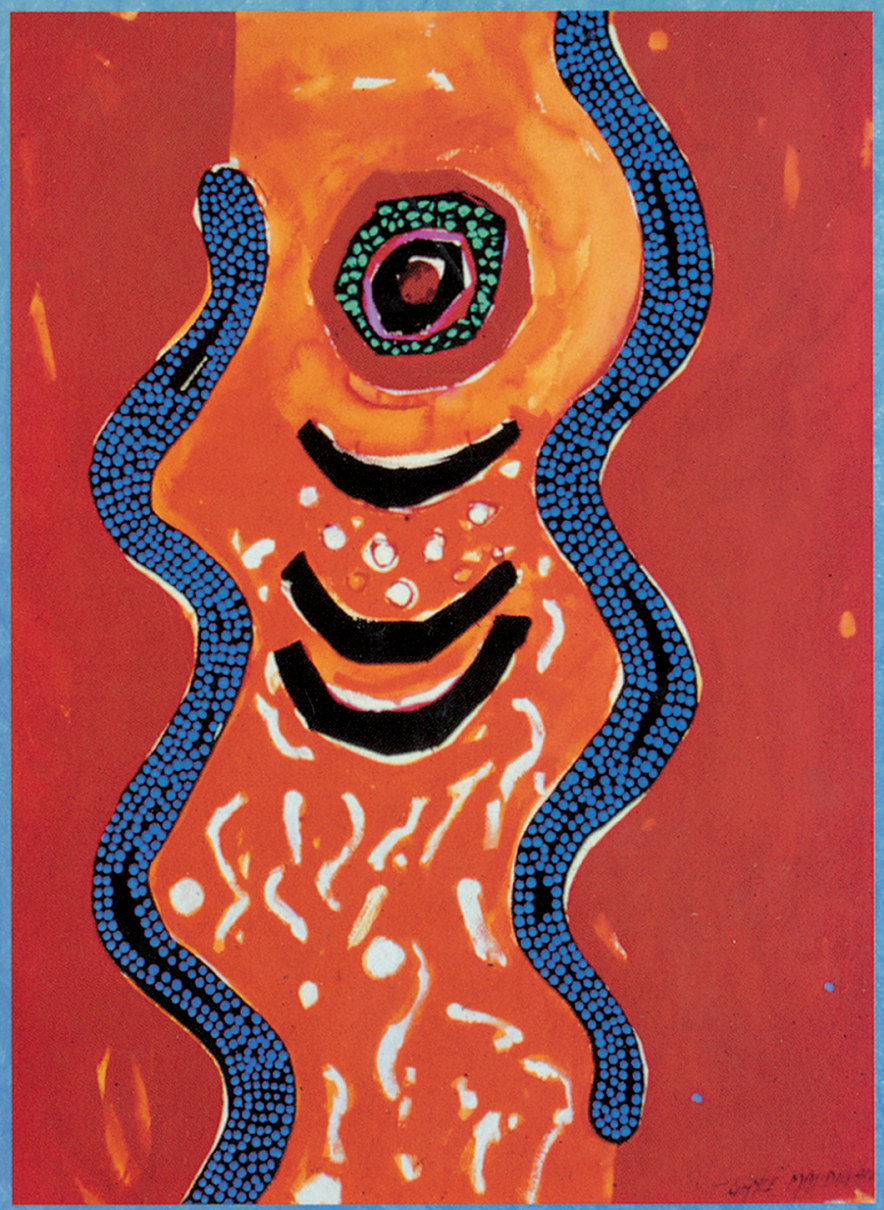




\section{-STUDIES IN-
IMPERIALISM}

General editor John M. MacKenzie

When the 'Studies in Imperialism' series was founded by Professor John M. MacKenzie more than thirty years ago, emphasis was laid upon the conviction that 'imperialism as a cultural phenomenon had as significant an effect on the dominant as on the subordinate societies'. With well over a hundred titles now published, this remains the prime concern of the series. Cross-disciplinary work has indeed appeared covering the full spectrum of cultural phenomena, as well as examining aspects of gender and sex, frontiers and law, science and the environment, language and literature, migration and patriotic societies, and much else. Moreover, the series has always wished to present comparative work on European and American imperialism, and particularly welcomes the submission of books in these areas. The fascination with imperialism, in all its aspects, shows no sign of abating, and this series will continue to lead the way in encouraging the widest possible range of studies in the field. Studies in Imperialism is fully organic in its development, always seeking to be at the cutting edge, responding to the latest interests of scholars and the needs of this everexpanding area of scholarship.

\section{Law, history, colonialism}

\section{MANCHESTER}




\section{AVAILABLE IN THE SERIES}

Britain in China

Community, culture and colonialism, 1900-1949

Robert Bickers

New frontiers

Imperialism's new communities in East Asia 1842-1952

ed. Robert Bickers and Christian Henriot

Western medicine as contested knowledge

ed. Andrew Cunningham and Bridie Andrews

The Arctic in the British imagination 1818-1914

Robert G. David

Imperial cities

Landscape, display and identity

ed. Felix Driver and David Gilbert

Science and society in southern Africa

Saul Dubow

Unfit for heroes

Reconstruction and soldier settlement in the Empire between the wars

Kent Fedorowich

Emigration from Scotland between the wars

Opportunity or exile? Marjory Harper

Empire and sexuality

The British experience Ronald Hyam

'An Irish Empire?'

Aspects of Ireland and the British Empire ed. Keith Jeffery

The South African War reappraised Donal Lowry

The empire of nature

Hunting, conservation and British imperialism John M. MacKenzie

Imperialism and popular culture ed. John M. MacKenzie

Propaganda and empire

The manipulation of British public opinion, 1880-1960 John M. MacKenzie

Gender and imperialism ed. Clare Midgley

Guardians of empire

The armed forces of the colonial powers, c. 1700-1964

ed. David Omissi and David Killingray

Colonial frontiers

Indigenous-European encounters in settler societies ed. Lynette Russell

Colonial masculinity

The 'manly Englishman' and the 'effeminate Bengali' Mrinalini Sinha

The imperial game

Cricket, culture and society

ed. Brian Stoddart and Keith A. R Sandiford

Jute and empire

The Calcutta jute wallahs and the landscapes of empire

Gordon T. Stewart

The French Empire at war, 1940-45

Martin Thomas

Travellers in Africa

British travelogues, 1850-1900 Tim Youngs 


\title{
Law, history, colonialism
}

\section{The Reach of Empire}

\author{
edited by Diane Kirkby \\ and Catharine Coleborne
}

MANCHESTER

UNIVERSITY PRESS

Manchester 
Copyright (C) Diane Kirkby and Catharine Coleborne 2001

While copyright as a whole and of all editorial matter is vested in Manchester University Press, copyright in individual chapters belongs to their respective authors, and no chapter may be reproduced in whole or in part without the express permission in writing of both author and publisher.

Published by MANCHESTER UNIVERSITY PRESS

ALTRINCHAM STREET, MANCHESTER, M1 7JA, UK

www.manchesteruniversitypress.co.uk

British Library Cataloguing-in-Publication Data

A catalogue record for this book is available from the British Library

Library of Congress Cataloging-in-Publication Data

A catalog record for this book is available from the Library of Congress

ISBN 10:0 719081955

ISBN 13:978 0719081958

First published 2001 by Manchester University Press

First digital, on-demand edition produced by Lightning Source 2010

The publisher has no responsibility for the persistence or accuracy of URLs for any external or third-party internet websites referred to in this book, and does not guarantee that any content on such websites is, or will remain, accurate or appropriate. 